\title{
ENFORGING THE CHILD'S RIGHT TO KNOW HER ORIGINS: CONTRASTING APPROACHES UNDER THE CONVENTION ON THE RIGHTS OF THE CHILD AND THE EUROPEAN CONVENTION ON HUMAN RIGHTS
}

\author{
SAMANTHA BESSON*
}

\section{ABSTRACT}

The justification of the child's right to know her origins and the fundamental interests underlying it have attracted a lot of attention in recent years. This article goes one step further and assesses that right's enforcement in practice together with its guiding principles. It starts by restating what the right consists in and what interests it protects according to different international human rights instruments. It then reveals the conflicts of rights that lie at the heart of the implementation of the right to know and explain its complexity. After considering the competing interests present, the article argues that none of these interests and rights should be regarded as absolute and suggests ways in which they can be balanced against each other. The recent evolution in the European Court of Human Rights (ECtHR) case law with its more nuanced balancing of the competing rights is contrasted with the Convention on the Rights of the Child (CRC)'s focus on the child's paramount interest. The article argues that these different approaches are reflected in national legal orders in Europe. By tracing the origins of this divergence back to those conflicting international legal paradigms and by proposing abstract adjudication principles to guide the concrete balancing of competing rights, the article hopes to contribute to a better understanding and ultimate reconciliation of the child's multiple identities - social and biological.

\footnotetext{
* Professor of Public International Law and European Law, University of Fribourg (Switzerland). This is a revised version of a conference presented on 7 September 2006 at the MAS in Children's Rights, University of Fribourg (Switzerland). I would like to thank all participants for their comments and questions. Many thanks are also due to Mrs Joanna Bourke-Martignoni, Mr Nils Kapferer and Ms Verena Seiler for their assistance at various stages of my research. Last but not least I would like to thank Mr John Eekelaar for his numerous and extremely helpful comments on an earlier version of this article.

International Journal of Law, Policy and the Family, Vol. 21, No. 2,

(C) The Author [2007]. Published by Oxford University Press. All rights reserved. For Permissions, please email: journals.permissions@oxfordjournals.org.
} 
INTRODUCTION

The question whether a child has a right to know her biological or genetic origins is one of the hardest issues to have arisen over the past 20 years. It is now broadly accepted that children who do not know one or both of their biological parents have a "vital interest' ${ }^{1}$ to identify them. This is the case of all children whose biological parentage has been split from their social or even from their birth parentage. It suffices to think of abandoned or displaced children, of adopted children, of children conceived by artificial insemination (AI) or of children born out of wedlock, who might have no social or even birth evidence of who their biological mother or father are.

Knowing one's origins is something most of us who know our parents take for granted, but for those who do not, it is an interest which has only very recently been acknowledged legally by the recognition of a full-blown right to know. This reluctance can be explained by the complexity of the issue. To start with, the situations in which a child's interest to know may be violated are so diverse as to prevent a holistic solution. For instance, an adopted child's relationship with her social or legal parents is different from an AI child's relationship with her birth parents or that of a child born out of wedlock with her father. Moreover, the ethical and legal issues are complicated by conflicting technical, psychological and sociological considerations that make a global evaluation of the child's situation difficult. Finally, and most importantly, the child's right to know conflicts with other people's rights as well as with public interests or even other interests of the child. One may think, for instance, of the competing rights to autonomy and privacy of the mother, the father, the adoptive parents or the gamete donor. All this has contributed to turning the topic of the child's right to know her origins into a 'Pandora's Box' (see Van Bueren, 1995: 37).

These difficulties have been confronted to a large extent in recent years. Whereas for a long time the right to know one's origins only concerned a small number of children, at least in western European societies, the number of such children has dramatically expanded, thus making the question more pressing. Because of the progress in biogenetics, a child may now be conceived in multiple ways. Another element is the increase in so-called non-conventional families whether hetero- or homosexual and hence the many ways in which a child may now be born and raised. Finally, the progress made in genetic research has facilitated the formal identification of a child's parents.

The child's right to know her origins is now broadly recognized and respected (see eg, Triselotsis, 1973; O’Donovan, 1988; Stewart, 1992; Hodgson, 1993; Van Bueren, 1995; LeBlanc, 1995; Freeman, 1996; Masson and Harrison, 1996; Fortin, 2003; Besson, 2005a). This has been brought 
about through national constitutional and legislative guarantees in the late 1980s. It has been the case in the UK, starting with adopted children in 1975 and finally extending the right to know to AI children in 2005, and in Germany for all children since 1988. Switzerland started protecting AI children's right to know in 1992 and finally extended the right to adopted and all other children in 2002, also making it an absolute right of the child. By contrast, France still does not expressly protect the child's right to know, even under the new 2002 legislation on anonymous birth ('accouchement sous $X$ '), and grants mothers, who have given birth anonymously, the right not to consent to the later release of identifying data.

The right to know has also been guaranteed, and this will be our object here, by international human rights law and in particular the ECtHR's case law since 1989 based on the 1950 European Convention on Human Right, (ECHR), the 1989 Convention on the Rights of the Child (CRC) and the 1993 Hague Convention on the Protection of Children and Cooperation in respect of Intercountry Adoption. All three conventions deal more or less expressly with the right to know one's origins, but the novelty of the CRC, and in particular of Articles 7 and 8 CRC, was that the child's right to know her parents qua child, and not only later as an adult, was expressly recognized for the first time. ${ }^{2}$

In this article, I discuss not so much the justification of the right to know one's origins itself and the fundamental interests underlying it, but the principles guiding its enforcement. Despite the national and international recognition of the right to know one's origins, important disparities remain in the enforcement of the right between international regimes and in the national implementations of these regimes. These disparities have been discussed at length in recent years, mostly focusing on the contrast between social and biological identity. The result is usually a stark opposition between those who consider the child's interest paramount and those who, on feminist or socio-cultural grounds, place the interest of the mother or of other concerned third parties first. In order to reverse the long-lasting and unjustified paramount importance given to the mother's and others' social interests, recent approaches have often granted the child's interest absolute priority over those interests. ${ }^{3}$ This is a mistake, I shall argue, as it has been done at the price of others' rights and hence of the social dimension of a child's identity (see eg, O’Donovan, 1988; Fortin, 2003: 383).

After a presentation of the different conflicting interests in presence in the right's implementation, the article argues, from a legal perspective, ${ }^{4}$ that none of these interests and rights should be regarded as absolute and suggests ways in which they can be balanced against each other. It starts by presenting some definitions and distinctions pertaining to the child's right to know her origins. The second section unpacks the conflict between the child's right to know and others' rights, and in particular 
the mother's or the donor's right to autonomy and privacy. There, I argue that solving those conflicts by giving priority to either rights contradicts the way human rights work and that the concrete balancing of rights is inescapable. In the third section, guidance for the weighing of competing rights is sought within international human rights instruments and the decisions of their international reviewing bodies. Most international texts and decisions do not, however, provide any definite guidance; they oscillate between giving priority to the child's right or to the mother's. This is the case, I argue, of the CRC and the absolute priority it gives to the child's right to know. By contrast, recent developments in the ECtHR's case law provide useful guiding principles in balancing the child's right to know with others' rights. As a result, the concretization of the right to know has been largely left to national law so far and state authorities benefit from a broad margin of appreciation. The last section assesses the implementation of the right to know one's origins in the four European countries mentioned before. The article ends with a proposal for balancing principles, procedures and authorities that enables the recognition of the child's biological identity without negating the importance of her social ties.

1. PUTTING FIRST THINGS FIRST: DEFINITION AND D IST INCTIONS

\section{A. Definition}

\section{General definition}

The right to know one's origins amounts to the right to know one's parentage, ie, one's biological family and ascendance, and one's conditions of birth. It protects each individual's interest to identify where she comes from.

The interest to know one's origins is usually regarded as sufficiently fundamental or " vital' $^{5}$ to give rise to a human right (see Freeman, 1996: 276-77; Besson, 2005c: 422-24). It is indeed deemed an important element in one's psychological balance to know where one comes from. Every one of us has a right to truth and hence to truth about one's origins (see eg, O'Donovan, 1988: 37-9; Eekelaar, 2006: chap 3). Moreover, adopted or AI children, who depend on the goodwill of authorities or their social parents to know about their origins, suffer from discrimination by comparison to children whose social and genetic parents match, but also to other children whose social and biological parents differ. ${ }^{6}$ Further subsidiary interests include the interest to know one's medical history and the interest in ascertaining legal rights such as inheritance rights (see O'Donovan, 1988: 29-36; Freeman, 1996: 277-79). 
The right to know one's origins is a dimension of the broader right to ascertain and preserve one's identity. Identity is a complex concept, which unsurprisingly has never been defined legally. In a nutshell, and to quote Freeman, identity is "what we know and what we feel. It is an organizing framework for holding together our past and our present and it provides some anticipated shape to future life' (Freeman, 1996: 290. See also Masson and Harrison, 1996: 278-79). It covers all sorts of memberships and in particular biological membership, but also familial, social, cultural and political memberships (see Stewart, 1992: 22627). The present article concentrates on biological membership and the right to know one's genetic parentage. Different guarantees of that right may be found in international human rights instruments. When that right is not recognized directly as such, it is usually based on the child's right to the respect of private life, to autonomy or freedom of expression.

The International Covenant on Civil and Political Rights

Although they do not guarantee the right to know one's origins expressly, two articles in the 1966 International Covenant on Civil and Political Rights (ICCPR) should be mentioned: Articles 17 and 24, paragraphs 2 and 3 .

In general, the right to know one's origins is said to derive implicitly from the right to privacy under Article 17 (Detrick, 1999: 145; Nowak, 2005: 432):

(1) No one shall be subjected to arbitrary or unlawful interference with his privacy, family, home or correspondence, nor to unlawful attacks on his honour and reputation.

(2) Everyone has the right to the protection of the law against such interference or attacks.

This provision is complemented by the right to birth registration under Article 24. The right to be registered immediately after birth is crucial in many respects. It allows the child to become official and is hence a condition for receiving many public benefits. It also enables the child to find out about her origins later on (see Nowak, 2005: 432). Moreover, the right to a name and a nationality are essential to the constitution and preservation of a child's identity and are therefore protected expressly by Article 24 paras 2 and 3:

(2) Every child shall be registered immediately after birth and shall have a name.

(3) Every child has the right to acquire a nationality. 
The European Convention on Human Rights

Although it does not guarantee the right to know one's origins expressly, one article should be mentioned in the 1950 ECHR: Article 8:

(1) Everyone has the right to respect for his private and family life, his home and his correspondence.

(2) There shall be no interference by a public authority with the exercise of this right except such as is in accordance with the law and is necessary in a democratic society in the interests of national security, public safety or the economic well-being of the country, for the prevention of disorder or crime, for the protection of health or morals, or for the protection of the rights and freedoms of others.

This article protects the right to respect for one's family and private life. The right to know one's origins is an essential part of the respect of private life and has been derived by the ECtHR directly from Article 8 ECHR since $1989 .{ }^{7}$ The ECtHR does not, however, define this right very precisely; the latter is said to cover the right to know one's parents' identity as well as the circumstances of one's birth. ${ }^{8}$ To mention just a few examples drawn from the ECtHR's case law, Article 8 ECHR has been said to protect the right of an adult placed as a child and who has remained in care until adulthood to consult his personal file (Gaskin v United Kingdom ${ }^{9}$ ), the right of a child to identify her father through DNA testing (Mikulic v Croatia and Ebrü v Turkey ${ }^{10}$ ), and the right of an adult to obtain a post-mortem DNA sampling of his presumed father (Jäggiv Switzerland ${ }^{11}$ ). So far, however, the ECtHR has paradoxically rejected the claim that the absolute birth secrecy granted in some European countries like France violates Article 8 ECHR (Odièurev France ${ }^{12}$ ).

\section{The Convention on the Rights of the Child}

The 1989 CRC is the first human rights convention to contain provisions granting explicitly not only the adult's, but also the child's right to know her origins. ${ }^{13}$ There are two important Articles, 7 and 8. According to Article 7:

1) The child shall be registered immediately after birth and shall have the right from birth to a name, the right to acquire a nationality and, as far as possible, the right to know and be cared for by his or her parents.

2) States Parties shall ensure the implementation of these rights in accordance with their national law and their obligations under the relevant international instruments in this field, in particular where the child would otherwise be stateless.

This provision repeats to a large extent pre-existing rights to registration, a name, nationality and care, and in particular the rights guaranteed 
in Article 24 ICCPR (see Hodgson, 1993: 256). The new right, however, under Article 7 is the right to know and be cared for by one's parents. This right should be interpreted broadly; the term 'parents' is said to include not only one's social or legal parents, but also one's biological or genetic parents together with one's birth parents (Hodgkin and Newell, 2002: 116-17; Freeman, 1996: 283-84; Masson and Harrison, 1996: 281-82). Of course, as we will see, reservations to the contrary were made by certain contracting parties, like the UK, the Czech Republic, Luxembourg and Poland in particular. These states also insisted on introducing the qualification 'as far as possible' to justify potential national derogations from the right to know.

The right to know one's parents ought to be understood in relation to the more general right to preserve one's identity. According to Article 8:

1) States Parties undertake to respect the right of the child to preserve his or her identity, including nationality, name and family relations as recognized by law without unlawful interference.

2) Where a child is illegally deprived of some or all of the elements of his or her identity, States Parties shall provide appropriate assistance and protection, with a view to re-establishing speedily his or her identity.

Article 8 is a truly innovative provision. It is the first time an international instrument guarantees identity rights, and to children (see Cerda, 1990; Detrick, 1999: 162). Its adoption was the result of an Argentinean proposal; at the time, Argentina was addressing the disappearance of many children during the 1970s and 1980s. At first, many countries opposed this renewed emphasis on the child's identity that seemed superfluous in view of Article 7. Moreover, it was regarded as inconsistent with secret adoption and protecting the identity of gamete donors, as they existed in some countries. As a result, a political compromise was reached. The provision was retained with the addition of a few provisos such as 'without lawful interference', 'illegally' or 'as recognized by law'. Nowadays, however, 'lawful' is understood to encompass national as well as international legal norms, so that national legal restrictions will not be permitted to contradict international obligations (Stewart, 1992: 225; Detrick, 1999: 165; Van Bueren, 1998: 119). Moreover, despite the addition of 'as recognized by law' to 'family relations', knowledge of one's family relations is usually interpreted as going beyond knowing one's legal parents and extends to biological and birth parents as well (Hodgkin and Newell, 2002: 125).

Despite its apparently innovative nature, Article 8 does not define the concept of identity. It gives three examples of what it includes: nationality, name and family relations, and in this sense it largely repeats Article 7. It is not exhaustive, however, and there are many other aspects of the child's identity which are deemed protected by the provision, for 
example the child's personal history, its race, culture, religion, language and its physical appearance, abilities and inclinations (see Hodgkin and Newell, 2002: 125; Hodgson, 1993: 265).

\section{B. Distinctions}

The personal scope of the right

a) The right-bearers

The importance of the interests protected by the right to know one's origins does not decrease with age. As a consequence, the bearers of the right to know one's origins are children as much as adults. The search for one's origins is indeed part of the search for one's identity and the right to know protects an interest that is as vital to a child as it is to an adult. Most national and international guarantees protect the right to know one's origins independently of age. It is the case, for instance, of Article 17 ICCPR and of Article 8 ECHR. ${ }^{14}$ By contrast, the specificity of Article 24 ICCPR, but most particularly Articles 7 and 8 CRC in this respect is to focus on the child's right only.

Of course, in practice, the actual means to protect the child's interest to know differ from those to protect an adult's right. Children are usually more emotional and less mature, and could be more easily destabilized by certain information. Practices vary therefore from one state to the next. Whereas in most European states, children have access only to their genetic data once they are eighteen, other states provide an immediate access to these data (see Van Bueren, 1998: 122-23). In any case, the release of information to young children is usually carefully controlled according to the child's best interest (see Article 3 CRC).

\section{b) The duty-bearers}

The main duty-bearer of the child's right to know her origins is the State. The state should primarily refrain from interfering with the child's right to know. It is also the state which has the means and hence the duty to arrange for registration at birth and for the collection and disclosure of all relevant data pertaining to a person's identity. Furthermore, it is usually the state which imposes legal duties under national law on individuals like the mother to identify the father or provide her own identification, but also which establishes legal sanctions against those who breach those horizontal duties. All national and international guarantees of the right to know primarily grant rights against the state.

To a certain extent, however, one may wonder whether individuals should not also be vested with direct duties pertaining to the right to know one's origins. For instance, the mother of a child knows most about the child's origins, so her cooperation in registering the child is 
crucial. Most national and international guarantees do not foresee a direct horizontal effect of the right to know, but they consider that right as vesting the state with negative and positive duties to make sure the right is protected against public and private violations (Besson, 2005a: 61). For instance, Article 7 CRC requires domestic law to make registration a compulsory duty both of parents and relevant administrative authorities. Similarly, Article 8 para 2 CRC suggests that the law should penalize those who breach the child's right to preserve her identity. According to the ECtHR's case law, Article 8 ECHR imposes positive duties on the state to prevent inter-individual restrictions of the right to know. ${ }^{15}$

\section{The Material Scope of the Right}

a) The negative right to know one's origins $v$ the positive right to know one's origins

The right to know one's origins is usually guaranteed as a negative right that protects one's interests against active violations by state authorities, but also - and that is most important given the importance of registering, preserving and opening access to birth data - as a positive right that protects against a passive omission of the state.

This is acknowledged by national and international guarantees of the right which protect both its negative and positive dimensions. Thus, Article 8 ECHR implies duties to register and then to preserve the data and make them accessible to the child. ${ }^{16}$ Article 7 of the CRC makes this even more precise in that it guarantees both the positive right to registration at birth and the positive right to preservation of these data for later consultation. When the father is unknown, state authorities have a duty to seek his identification (see Hodgkin and Newell, 2002: Article 7). Article 8 para 2 CRC also emphasizes positive duties of assistance and protection to speedily re-establish the possibility for a child to preserve her identity. The same registration and preservation duties may be derived from Article 24 ICCPR. Of course, the scope of positive duties and their intensity is more difficult to pre-determine than those of negative duties. As a result, the margin of appreciation of national authorities is broader. ${ }^{17}$ Article 8 para 1 CRC, for instance, refers to states 'undertaking to preserve' the child's identity and Article 8 para 2 CRC calls for 'appropriate' measures to re-establish the child's identity (Hodgson, 1993: 266).

b) The right to know one's parents $\mathrm{v}$ the right to be with one's parents In principle, the right to know one's parents does not imply the right to meet them and to be with them. Parents might have those duties 
from other sources, but they are not founded in the same interests of the child. Imposing contact on the mother or the father is far more demanding than requiring them to be identifiable. Moreover, if the right to know one's parents' identity reflects the importance of one's biological ties besides social ones, requiring contact with them would rank the former over the latter (Wallbank, 2004: 260; Fortin, 2003: 386-90; 411-13).

National and international guarantees of the right to know one's origins do not therefore usually foresee this extension of the right. There is an exception in Article 7 CRC, however. This right to contact and be cared for by one's biological parents may be explained by reference to further interests of the child protected in the Convention. Article 7 should indeed be read in light of the rest of the Convention and in particular of Articles 9 and 18 CRC, which guarantee the child's right to have a relationship with her parents (see Fortin, 2003). Like the right to know, however, the right to be cared for by one's biological parents, besides one's social parents, is qualified by the words 'as far as possible'. The burden of proof is nevertheless said to lie on state authorities; the Convention's presumption is indeed that, in ordinary circumstances, children are best off with their biological parents (see Hodgkin and Newell, 2002: 119).

\section{ENFORCING THE RIGHT: CONFLIGTS OF RIGHTS}

Enforcing the child's right to know her origins implies going further than respecting the material and personal scope of the specific rights and duties it generates. Human rights do not usually arise alone and they often enter in conflict with the other rights and interests with which they coexist. Human rights enforcement is therefore to a large extent about resolving conflicts of rights and interests, and children's rights' enforcement is no exception in this regard (see eg, Eekelaar, 2006: chap 6).

To start with, conflicts of human rights are common. Human rights protect fundamental interests and values, which are necessarily plural and hence may conflict with each other. ${ }^{18}$ True, many pre-existing conflicts of interests are solved before a right is recognized; their resolution is precisely what delineates a right's material scope. Most conflicts of rights arise, however, after a right has been recognized and guaranteed in a legal instrument; they arise when specific rights and duties are generated out of an abstract right and hence when they conflict with other specific rights and duties (Besson, 2005c: 426).

The rights in conflict with the child's right to know include the rights of the biological mother, the biological father, the mother's husband, the adoptive parents and the gamete donor (Besson, 2005a: 42-3). 
The biological mother could have a fundamental interest to keep her identity or that of the biological father secret when giving birth; she could have been raped or been the victim of an incestuous relationship. The biological mother's husband, who may have brought up his wife's child as his own or even recognized her legally as his own, may also have a fundamental interest to keep his social ties to the child untouched by identity revelations. Adoptive parents could have a similar interest to protect their familial, social and psychological ties to the child from the identification of the child's biological parents. Finally, gamete donors may have a sole intention to help out sterile couples and not want to become mother or father, and hence have a fundamental interest in privacy. Some have argued in this respect that one would find less gamete donors if the donation secrecy were no longer guaranteed. Other studies show, however, that this need not be feared and that once legal claims, such as paternity claims, are excluded, donors remain as interested (Besson, 2005a: 43).

In some cases, the interest of the child may also coincide with that of the mother. For instance, when an adulterous or raped mother's life is threatened if she gives birth to a child resulting from that adulterous relationship or a rape, the child's life will also be threatened. In those cases, birth secrecy may be said to be the best way to secure both the child's and the mother's right to life. Moreover, other interests of the child may conflict with the child's right to know her origins. In some cases, the child might be better protected by not knowing certain elements of her biological origins. Reconciling the child's interest to know with her other interests is difficult, however. A guiding principle may be found in Article 3 CRC, which makes the child's best interests a primary consideration. Prima facie, however, Article 7 CRC appears to provide much stricter guidelines and be less subjective than Article 3. Thus, short-term considerations pertaining to the child's welfare should not take priority over her objective moral interests. ${ }^{19}$ According to some authors, however, it follows from the Convention's structure that Article 7 CRC should be read in conjunction with general provisions such as Article 3, thus imposing limits on the right to know in cases where the information would be blatantly contrary to the child's best interest (see Hodgkin and Newell, 2002: Chap 7).

In sum, a concrete balancing of interests will have to take place to resolve those various conflicts of rights and interests (Besson, 2005a: 66-70). Of course, this is not to say that abstract guidelines as to how to proceed with this balancing are never useful. Abstract hierarchies of rights are rare however, and, even when they exist, they cannot solve conflicts of rights between rights of equal weight or rights which only conflict with each other in concrete cases and not in others 
(Besson, 2005c: 426, 437-39). As a matter of fact, the difficulties raised by the potential conflict between the right to know and other rights is enhanced by the fact that these rights is usually rights that are ranked equally with the child's right. Moreover, the rights in conflict are often the same on each side. One may think, for instance, of the mother's or the donor's right to autonomy, right to privacy or freedom of expression.

True, one may argue that balancing the right to know might lead to violating the inner core ('noyau fondamental' or 'Kerngehalt') of the right and hence it becomes devoid of any content. Human rights protect peripheral and core interests and hence generate specific rights which lie either at the core or at the periphery of the abstract right. One may therefore argue that a human right's inner core needs to be protected against any restriction and hence escape any concrete balancing with other rights, just as it would pre-empt public interests in case of conflict. ${ }^{20}$ This would, for instance, protect the child's right to know in countries where birth 'under $\mathrm{X}$ ' is authorized and hence undermines completely, and from the very beginning, the right to know who one's parents are. This objection ignores, however, that other competing rights have inner cores as well. Thus, providing the right to know priority and hence absolute protection may violate others' rights' inner core (Besson, 2005a: 67-8). Thus, cases where the child's right to know is given absolute abstract priority over the mother's right to privacy might violate the mother's right's inner core. Moreover, in case of conflicts of fundamental rights' inner cores, pragmatic solutions need to be sought in the balancing of those rights (Besson, 2005c: 439-43; 451).

In a nutshell, balancing cannot be avoided in case of conflict between the child's right to know and other rights and interests. This does not mean, however, that this balancing cannot be guided legitimately and efficiently. Space precludes discussing this issue at length here, but generally one may argue that the weighing of conflicting rights is done according to the weight of the specific interests protected in each case. According to the maximization of moral reasons requirement, the prioritization of the weightier right over the other is possible $;^{21}$ mutual restrictions of the rights in conflict are called for by reference to the interests' respective weight and the proportionality principle (see Besson, 2005c: Chap 12). Further detailed procedures, authorities and principles can and should be developed to adjudicate between the competing interests. It is interesting to examine whether further guiding principles may be found in the international human rights instruments presented before and how they translate into national concretizations of the right in Europe. 
3. SEEKING GUIDANCE: INTERNATIONAL PRINCIPLES AND REVIEW OF THE RIGHT'S ENFORCEMENT

In principle, the implementation of international human rights lies primarily in the hands of national authorities. In most cases these are, however, directly bound by international human rights norms. Adjudicating principles may therefore be found in some of those instruments. Among the international bodies concerned with the enforcement of the international right to know one's origins and susceptible to produce adjudication guidelines, one may mention two political bodies: the UN Committee on Human Rights (CHR) responsible for monitoring the enforcement of the ICCPR and the UN Committee on the Rights of the Child (CtRc) in charge of monitoring the enforcement of the CRC. The third body that will be considered is judicial: the European Court of Human Rights in charge of reviewing national decisions based on the ECHR.

\section{A. The Committee on Human Rights}

ICCPR provisions do not provide any guidelines as to how to resolve potential conflicts between Articles 17 and 24 ICCPR and other rights.

The CHR has produced many recommendations and guidelines as to how the right to know one's origins should be implemented in practice and under various aspects (see Detrick, 1999: 145-46). None of them, however, address the conflict of rights that may emerge between the child's right to know and others' rights. Nor do they provide criteria as to how to balance conflicting rights in those situations. This should come as no surprise given the eminently negative approach to the right to privacy often adopted by the Committee (Van Bueren, 1995: 45).

\section{B. The Committee on the Rights of the Child}

Articles 7 and 8 CRC do not settle the issue of which among the child's interests should prevail in case of conflict between her interest to know her origins and her other interests. Nor do they provide any criteria as to how to balance the child's interests with those of others in case of conflict. In fact, this silence can be interpreted positively. If one refers to the Convention's aim and the general ideology behind it (see eg, Archard, 2002; Besson, 2005b), it may be said to minimize the importance of such conflicts. More precisely, based on a holistic approach to the Convention, one may even regard Articles 7 and $8 \mathrm{CRC}$ as giving a clear and absolute priority to the interests of the child over those of her parents (Van Bueren, 1995: 49; Hodgkin and Newell, 2002: Article 7).

True, Article 7 para 1 CRC grants the child a right to know only 'as far as possible'. The meaning of this proviso is contested. According to 
some, it means that the right should be implemented as far as it is possible as a matter of fact. And this in turn would imply that the right to know one's origins is absolute and cannot be conditioned on the respect of any other legal duty or right. ${ }^{22}$ This interpretation is too limited, however. A more complete interpretation is that the right to know is granted only as far as this is possible within the limits of the legal order and that illegal restrictions to the right to know are prohibited ${ }^{23}$ This interpretation accounts for the qualifications in Article 7 para 2 and Article 8 paras 1 and 2, under which the state's further obligations stemming from national but also from international law are restated. What this also means is that other international human rights obligations may conflict with the child's right to know and in particular those obligations pertaining to the mother's or third parties' rights under other national and international instruments. As a result, these conflicts need to be resolved when enforcing the child's right to know.

The CtRC is unlikely, however, to clarify the situation by providing criteria and guidelines as to how to balance those conflicting interests. There is indeed no mechanism for individual petition under the CRC. True, the Committee has had many occasions to make recommendations regarding incomplete national enforcement of the child's right to know her origins in contracting parties. ${ }^{24}$ There is no trace in the Committee's resolution, however, of principles that could guide the balancing of the right of the child to know and her best interest or other people's rights, and in particular those of the mother, when the conflict at stake has not been resolved by national authorities to the absolute advantage of the parent's right. As a result, national authorities have a large margin of appreciation provided they do not give absolute priority to the parents' rights, and do, as we will see, diverge in their interpretations of the scope and degree of the duties imposed by Articles 7 and 8 CRC (Hodgson, 1993: 266).

\section{The European Court of Human Rights}

Article 8 para 2 ECHR expressly recognizes the possibility of restricting the right to know one's origins when it conflicts with other rights. It also provides the conditions that need to be respected and hence some balancing guidelines. These are legality, the existence of rights or interests of others and proportionality. One usually adds a fourth condition, ie, the respect of the right's inner core.

In its case law, the ECtHR has confirmed that the right to know one's identity is not absolute. The determination of the extent of the state's positive duties resulting from the right to know one's origins requires balancing that right with others' rights. ${ }^{25}$ When balancing rights, however, the Court respects the state's margin of appreciation. The latter is particularly broad in matters pertaining to private life and identity. 
There are indeed many ways 'of ensuring "respect for private life", and the nature of the State's obligation will depend on the particular aspect of private life that is at issue'. ${ }^{26}$

For a long time, the Court was quite respectful of the national margin of appreciation in the case of violations of the right to know one's origins. The criterion for considering legal restrictions on the right compatible with Article 8 ECHR was, according to the Mikulic case, that the system provides, in the absence of an obligation for presumed fathers to submit themselves to a DNA test, 'alternative means enabling an independent authority to determine the paternity claim speedily'. ${ }^{27}$ This flexible approach to balancing culminated in the Odière case. In that case, Ms Odièvre argued that the French practice of anonymous ("under $\mathrm{X}^{\prime}$ ) birth, and the fact that her mother had been allowed to retain her identity from her daughter, infringed Article 8 ECHR. The Court considered that the possibility that the claimant born 'under X' might be provided with non-identifying data, together with the provisions of the legislation of 2002 authorizing an independent council to waive confidentiality with the mother's consent, were sufficient evidence of France's efforts to seek a balance and to ensure sufficient proportion between competing interests. ${ }^{28}$

The Court's decision in Odièrre has been heavily criticized, however. ${ }^{29}$ According to the dissenting judges in the case, the contracting parties' margin of appreciation should not be regarded as exempting the Court from its duty to review the way in which the rights had been balanced as it did. Moreover, the problem in the decision lay in the fact that French law, by giving absolute priority to the right of the mother, who retains the right to decide on releasing her information even under the legislation of 2002, precludes any balancing of the interests at stake. As a result, and without acknowledging it, the Court gave the mother's right absolute priority and hence violated the child's right's inner core. $^{30}$

In two 2006 decisions Ebrü and Jäggi, the Court has taken those critiques seriously and has demonstrated its intention to review very closely the weighing-up of the right to know at national level. ${ }^{31}$ In the Jäggi case, the Court states that the scope of the state's margin of appreciation depends not only on the abstract right at stake, but also on the specific right in question and hence on the interest protected in the case at hand. As explained above, some interests are more fundamental than others, and hence some parts of a right, also referred to as the right's inner core, are more fundamental than others. In Jäggi, the Court makes the dissenting judges' opinion in Odière its own..$^{32}$ It considers that the right to identity, and hence to know one's origins, belongs to the inner core of the right to respect of one's private life. ${ }^{33}$ In such cases, the Court argues, it should review the state's balancing of the rights in conflict very closely. ${ }^{34}$ Applying this close scrutiny, the Court judges that Switzerland infringed Article 8 ECHR in 
refusing an adult man the right to obtain a post-mortem DNA sampling of his dead father even though this required exhuming the latter.

With its new approach in Ebrü and Jäggi, the Court seeks a fair equilibrium between the competing rights, instead of granting absolute priority to either the child's right to know or the parents' right to privacy. ${ }^{35}$ These decisions will remain landmarks in the ECtHR's case law on this question and will require important revisions of certain European approaches to the conflict between the child's right to know and other's rights.

4. RESOLVING CONFLICTS: NATIONAL CONCRETIZATIONS

OF THE RIGHT

\section{A. National Concretizations of the International Right to Know}

The enforcement of the child's right to know her origins diverges from one country to the next in Europe, even though the constitutional and legislative guarantees which have gradually emerged since the 1980s are often similar (see eg, Besson, 2005a: 43).

These divergences are even more surprising as these different countries are all bound by the same international guarantees and in particular by the ECHR and the CRC. These differences often arise from socio-cultural and historical differences which have led to placing more weight on certain interests than others when interpreting the same international rights (see O'Donovan, 2000; 2002); the broad margin of appreciation left to member states on these difficult issues explains divergences. Moreover, given the contrasting paradigms in each international instrument's balancing guidelines and case law, it should come as no surprise that priorities are set differently in European countries. Thus, the indeterminacy of the 'as far as possible' proviso in Article 7 para 1 CRC has justified opposite decisions in Germany and in Switzerland, as we shall see. It is also the case of Article 8 ECHR which until recently had been interpreted inconsistently by the ECtHR due to the respect for states' margin of appreciation. Finally, divergences in national concretizations of the right to know can also be explained by the tension that exists since 2006 between the resolutely balanced latest case-law of the ECtHR based on Article 8 ECHR and the absolute priority given to the child's right in the CRC's guidelines pertaining to Articles 7 and 8.

With respect to tensions between international obligations pertaining to the right to know, Article 60 ECHR phrases a favour principle according to which ECHR guarantees are only minimal and according to which the ECHR should not be understood as limiting or derogating from stronger protection guarantees at national or international level. In this sense, Articles 7 and 8 CRC could be interpreted by national 
authorities as providing greater protection to the child and the absolute protection of the child's right to know as taking priority over others' rights. The problem is, however, that this is done at the price of the inner core of the mother's right to privacy (Besson, 2005a: 42-3). The protection granted by those national authorities should not therefore be understood as greater protection of a right if it is at the expense of another right's protection. Articles 7 and 8 CRC should as a consequence be interpreted in conformity to Article 8 para 2 ECHR.

Similar conflicts may arise between national guarantees and Articles 7 and 8 CRC in certain countries or between them and Article 8 ECHR in others. True, such conflicts should not arise in principle given the primacy of international (human rights) law over national (constitutional) law. ${ }^{36}$ In most European countries, however, such conflicts are resolved in favour of the inner core of a right when it is granted better protection in national law. ${ }^{37}$ Certain national authorities could therefore regard the absolute protection of the right to know's inner core in national law as taking priority over the ECtHR's more balanced interpretation of Article 8 ECHR. In cases where both rights are equally strong, however, as in the case of the conflict between the child's right to know and the mother's right to privacy, and where both inner cores might be violated, it is clear that the most balanced resolution of the conflict of rights according to Article 8 para 2 ECHR should be chosen (Besson, 2005a: 68-70).

This conclusion in favour of a balanced approach to the enforcement of the right to know in national law raises a difficult dilemma for countries where international or national legal guarantees give absolute priority either to the child's right or to the mother's.

\section{B. Four Examples}

The four countries discussed in this section can be placed along a spectrum that starts from the absolute weight given to the mother's right in France and ends with the absolute priority recognized to the child's right in Switzerland. The UK and Germany are situated at the centre of the spectrum with a practice of accommodating all interests in presence; a relative priority is often given to the mother in the UK, while the child usually gets relative priority over the mother after the balancing of rights in Germany (see eg, O'Donovan, 2002). Despite original divergences, there has been a perceptible tendency towards harmonization in recent years. This is due to international pressure and in particular that of the CRC in favour of the child's right, on the one hand and of the ECtHR's recent case-law in favour of both the mother's and the child's right, on the other. Among the states which made reservations to Articles 7 and 8 CRC in 1989, only Poland, the Czech Republic and Luxembourg still guarantee absolute birth secrecy. 


\section{France}

French law does not guarantee the child's right to know her origins. Historically, indeed, maternity and motherhood were regarded as clearly separate and a mother could give birth secretly. As a result, there was for a long time no right to know one's origins when the mother or a donor had chosen secrecy (see eg, O'Donovan, 2002). Since the CRC came into force and under general pressure in Europe, the right to give birth anonymously was nuanced in a new law in 2002. True, secret birth has not been abolished, but it can be lifted on request of the child and with the assent of the mother. Other non-identifying data have also been made more readily accessible through independent authorities. In 2003, the French practice was deemed compatible with Article 8 ECHR in the Odière decision discussed above. ${ }^{38}$

The situation in France has been rightly criticized ever since, however. Thus, the CtRC stated that the measures taken by France do not fully reflect the provisions of the Convention. ${ }^{39}$ Moreover, critiques were also expressed within the ECtHR by dissenting judges in the Odièvre case, who regarded the right to know as entirely sidestepped. Interestingly, the most recent ECtHR's case law on the issue, and in particular the Jäggi decision, has incorporated the dissenting judges' approach; it emphasizes the importance of the balancing of all rights in presence without any absolute and abstract priority being given to any of them. This renewed willingness to review the national balancing of competing rights clearly signals that the Odière case would no longer be decided along the same lines today and that French law will most probably have to be amended accordingly.

\section{UK}

The child's right to know her origins is guaranteed under British law. It is most particularly the case in adoption law where the adopted child's rights have been well protected since 1975. Moreover, the Access to Personal Files (Social Services) Regulations, 1989 for other children was adopted as a consequence of the Gaskin case. The child's right to know is not absolute, however, and has to be balanced against the parent's or donor's right when those rights are in conflict (see eg, O'Donovan, 2002).

Problems started to emerge in British law when AI was regulated. At first, AI children were not granted any right to know their biological parents as the donor's identity could be kept entirely secret. When the CRC came into force, therefore, the UK made a reservation to Article 7 CRC to preserve donors' rights. Only those parents could be regarded as 'parents' according to Article 7 CRC who, as a matter of national law, are treated as parents. ${ }^{40}$ Gradually, under European pressure and following the reception of the Human Rights Act (1998) (see eg, Herring, 1999; Eekelaar, 
2002; 2006 chaps 3 and 6; Choudry and Fenwick, 2005; Fortin, 2006), a revision of the secrecy practice occurred in 2002 (see eg, Frith, 2001). Since then the law has been changed and, according to the new regulations entered into force in 2005, the child's right has to be protected and weighed against the donor's interest (see Almack, 2006; Wallbank, 2004) ${ }^{41}$ In sum, the British approach to the child's right to know has now turned into a non-discriminatory and more balanced one, that duly respects the inner core of all competing rights.

\section{Germany}

The child's right to know her origins has been protected in Germany since 1988, when the German Federal Constitutional Court anchored this right in the human dignity and personality rights of the German Basic Law. ${ }^{42}$

In recent years, and under the pressure of pro-life groups in particular, so-called 'baby-flaps' ('Baby-klappen') have re-appeared in Germany (see eg, Swientek, 2001). As a result, the practice of secret abandonment of children is now tolerated, although it jeopardizes the child's basic right to know about her parentage and hence gives absolute priority to the mother's interest in those cases. The justification for this restriction to the child's right to know is said to lie in the 'as far as possible' proviso in Article 7 para 1 CRC and in both the mother and child's right to life which is ranked higher than the right to know by the German Basic Law (see O'Donovan, 2002). The CtRC expressed concern about this, but the ECtHR's decision in Odière indirectly condoned the practice. With changes in the ECtHR's case law, it is highly probable that German law will now have to move towards a more balanced adjudication of the conflict between the interest of the child to know and those of the parents.

\section{Switzerland}

The child's right to know her origins is protected in an absolute fashion in Switzerland. This applies to all children equally (see eg, Besson, 2005a; Aebi-Müller, 2005; Reusser and Schweizer, 2000). The question has recently received more attention due to the re-emergence of babyflaps in Switzerland.

It took around 20 years for the generalization of the right to know one's origins to occur. In the 1980 s, the right to know one's origins was recognized in the federal case law as based on the unwritten right to personal freedom. It was then expressly anchored in the federal Constitution in 1992 and legislation in 1998, but only within the strict framework of the regulation of medically assisted reproduction and AI only. It was guaranteed as an absolute right of the child. Rapidly, this created inequalities 
between AI children and adopted children whose right to know their origins existed but not in an absolute fashion. By that time it had also become clear that Article 30 of the 1993 Hague Convention, but most specifically Articles 7 and 8 CRC, which have direct effect in Swiss law, required adoption law to be amended. Both articles were interpreted by the legislator in 2003, and by the Swiss Federal Tribunal in 2002, as guaranteeing an absolute right to know one's origins as far as practically possible. ${ }^{43}$

In view of the latest evolution in the ECtHR's case law, the absolute approach to the child's right chosen in Swiss law may now be deemed in violation of other fundamental rights, not only national but also international (Besson, 2005a: 69-70). The ECtHR's recent decision in Jäggi shows how Swiss authorities may be condemned for not having sufficiently balanced the father's right against those of his child. The reverse should also be true, however, and a fair balancing of rights should occur in all cases. Accordingly, the 2002 Swiss Federal Tribunal's case law that gives absolute priority to the child's right to know, although based partly on Article 7 CRC, will have to be revised to respect the balancing requirement under Article 8 ECHR.

\section{A PROPOSAL QUA GONCLUSION}

The increasing legal recognition since the 1980s of the child's right to know her origins has been a clear progress that guarantees the child's vital interest in identity against her parents' rights to privacy or autonomy. This article has argued, however, that that right should not be granted absolute protection as it threatens to or is actually already threatening parents' rights in some European countries. On the contrary, a careful balancing should take place in each concrete case to make sure both the child's and her parents' interests are taken into account.

Although concrete balancing is necessary to avoid the absolutism of abstract solutions, abstract balancing guidelines can and should be developed both at national and international level (Besson, 2005a: 70; Besson, 2005c: chap 12; Eekelaar, 2006: chap 6). First of all, specific national authorities should be established that offer the guarantees of independence and the know-how needed to balance the interests in issue. ${ }^{44}$ Most European countries now constitute independent administrative bodies of that kind. Second, procedures before these authorities should be clear and speedy so as to ease the resolution of substantive questions whose complexity prevents an abstract solution. ${ }^{45}$ Moreover, burdens of proof could be alleviated in certain conditions as, for instance, when the child is badly affected or ill or when the mother's life is in danger. Finally, balancing criteria should be carefully identified. More particularly, principles of legality, proportionality ${ }^{46}$ and the existence of 
rights or interests of others should be strictly respected so as to frame the balancing. ${ }^{47}$ Additionally, the inner core of each right should be guaranteed in an absolute fashion, so as to preclude ex ante 'under X' birth practices or baby-flaps.

The final aim in the enforcement of the child's right to know her origins should be to reduce the growing gap between her biological, social and legal identities. While the latter's distinct existence ought to be openly acknowledged, their complementarity should also be revealed once they are about to be known. Only so will each individual child be able to live a coherent albeit truthful existence. This has a price, however: openly balancing the rights of all individuals concerned in the child's identity-constitution process.

\section{NOTES}

1 See European Court of Human Rights (ECtHR), Jäggiv Switzerland, 58757/00 [2006] ECHR (13 July 2006), para 38; ECtHR, Odièvre v France, 42326/98 [2003] ECHR 86 (13 February 2003), para 29 .

${ }^{2}$ See Besson, 2005b on the equality of rights between adults and children.

${ }^{3}$ See eg, Freeman, 1996. For an attempt at compromise, see eg, Wallbank, 2004; Ronen, 2004; Wilson, 1997.

4 The article leaves aside complex philosophical, psychological and sociological issues pertaining to identity-building, as well as further bioethical questions (see eg, Ronen, 2004; Wilson, 1997).

5 See ECtHR, Jäggi, para 38; ECtHR, Odièvre, para 29.

${ }^{6}$ See for a cautious approach to the analogy, O'Donovan, 1988: 28, 36. See in favour of the analogy, Freeman, 1996: 279-82; Van Bueren, 1998: 121, 126; Wallbank, 2004; Besson, 2005 a.

7 See ECtHR, Gaskin v United Kingdom, 10454/83 [1989] ECHR 13 (7 July 1989).

8 ECtHR, Odièvre, para 29. See also ECtHR, Jäggi, para 25.

${ }^{9}$ See ECtHR, Gaskin.

${ }^{10}$ See ECtHR, Mikulic v Croatia, 53176/99 [2002] ECHR 27 (7 February 2002); ECtHR, Ebrü v Turkey, 60176/00 [2006] ECHR (30 May 2006).

11 See ECtHR, Jäggi.

12 See ECtHR, Odièvre.

${ }^{13}$ One should also mention Article 30 of the Hague Convention on the Protection of Children and Cooperation in respect of Intercountry Adoption 1993, which repeats Article 7 CRC. See Van Bueren, 1998: 122.

${ }^{14}$ See ECtHR, Jäggi, para 40 that reverses the Commission's opinion in ECtHR, Gaskin, para 89 in respect of the importance of age in exercizing the right to know one's origins.

${ }_{15}$ See eg, ECtHR, Jäggi, para 33.

16 See eg, ECtHR, Jäggi, para 33.

17 See eg, ECtHR, Jäggi, para 33.

18 See Besson, 2005c: chap 12 on conflicts of fundamental rights in general.

19 See O'Donovan, 1988: 37; Freeman, 1996: 286. See also Committee on the Rights of the Child, Luxembourg IRCO, Add. 92, para 11 and 29. Contra: Ronen, 2004 (based on Eekelaar, 1994), who argues for the child's right to construct her own identity dynamically.

${ }^{20}$ See eg, the decision by the Swiss Federal Tribunal, ATF 128 I 63.

${ }^{21}$ Contra: Eekelaar, 2006: chap 6, who argues that prioritization of the child's interest is required where the interests are of similar weight to compensate for the child's innocence. It seems, however, that the latter is already factored into the weighing of the child's interest to know the truth about her identity.

${ }^{22}$ See the decision by the Swiss Federal Tribunal, ATF 128 I 63, 73 para 4.

${ }^{23}$ See eg, on the German approach to the legality of 'baby-flaps' in view of Article 7 CRC, O’Donovan, 2002. 
${ }^{24}$ See eg, Luxembourg IRCO, Add. 92, para 11 and 29.

${ }_{25}$ ECtHR, Odièvre, para 40. See also ECtHR, Jäggi, para 33.

${ }^{26}$ ECtHR, Odièure, para 46.

${ }^{27}$ ECtHR, Mikulic, para 64.

${ }^{28}$ ECtHR, Odièure, para 49.

${ }^{29}$ See eg, Besson, 2005a with further references.

${ }^{30}$ ECtHR, Odière, Joint Dissenting Opinion of Judges Wildhaber et al, para 6-7, 18 and especially 11: 'Turning, firstly, to the margin of appreciation itself, its extent may depend not only on the right or rights concerned but also, as regards each right, on the very nature of the interest concerned. Thus, certain aspects of the right to private life are peripheral to that right, whereas others form part of its inner core. We are firmly of the opinion that the right to an identity, which is an essential condition of the right to autonomy and development, is within the inner core of the right to respect for one's private life. Accordingly, the fairest scrutiny was called for when weighing up the competing interests'.

${ }^{31}$ See eg, ECtHR, Jäggi and ECtHR, Ebrü.

${ }^{32}$ Compare ECtHR, Odièvre, Joint Dissenting Opinion of Judges Wildhaber et al, para 11 and ECtHR, Jäggi, para 37.

${ }_{33}$ ECtHR, Jäggi, para 37.

${ }^{34}$ ECtHR, Jäggi, para 37.

${ }^{35}$ ECtHR, Jäggi, para 38-44; ECtHR, Ebrü, paras 95-7.

${ }^{36} \mathrm{See}$ eg, the decision by the Swiss Federal Tribunal, ATF 125 II 417, 425 para 4c.

${ }^{37}$ See eg, the decision by the Swiss Federal Tribunal, ATF, 22 December 1999, SJ 2000 I 489. See also Cottier and Hertig, 2000.

${ }^{38}$ ECtHR, Odièure, para 49.

${ }^{39}$ France IRCO, Add. 20, para 14.

${ }^{40} \mathrm{CRC} / \mathrm{C} 2 / \operatorname{Rev} 8$, p 42.

${ }^{41}$ Children born as a result of donations after April 2005 will have a right of access to the identity of the donor once they reach the age of 18. See The Human Fertilisation and Embryology Authority (Disclosure of Donor Information) Regulations 2004 No 1511, http://www.bailii.org/ uk/legis/num_reg/2004/20041511.html. See also Department of Health, Anonymity to be Removed from Future Sperm, Egg and Embryo Donors, Press Release 2004/0023. See also Rose v Secretary of State for Health [2002] 2 FLR 962.

${ }^{42}$ BVerfGE 79, 256 and $96,56$.

${ }^{43}$ ATF 128 I 63, 76-78 para 4.4 and 5.

${ }^{44}$ See eg, ECtHR, Mikulic, para 64 and ECtHR, Ebrü, para 95.

${ }^{45}$ See eg, ECtHR, Mikulic, para 64 and ECtHR, Ebrü, para 95.

${ }^{46}$ However, for a critique of the utility of proportionality in conflicts of rights as opposed to conflicts of rights and public interests, see Besson, 2005c: chap 12.

${ }^{47}$ See eg, ECtHR, Jäggi, paras 38-9 and ECtHR, Ebrü, para 95.

\section{REFERENCES}

Aebi-Müller, R. (2005) 'Anonyme Geburt im Schweizerischen Rechtssystem', Jusletter, 26 September.

Almack, K. (2006) 'Seeking sperm: Accounts of lesbian couples' reproductive decision-making and understandings of the needs of the child', International Journal of Law, Policy and the Family, 20, 1-22.

Archard, D. W. (2002) 'Childrens' rights', Stanford Encyclopedia of Philosophy, http://plato.stanford. edu/entries/rights-children.

Besson, S. (2005a) 'Das Grundrecht auf Kenntnis der eigenen Abstammung', Zeitschrift für Schweizerisches Recht, 1, 39-71.

Besson, S. (2005b) 'The non-discrimination principle in the Convention on the Rights of the Child', International Journal of Children's Rights, 13:4, 433-61.

Besson, S. (2005c) The Morality of Conflict. Reasonable Disagreement and the Law, Oxford: Hart.

Van Bueren, G. (1995) 'Children's access to adoption records: State discretion or an enforceable international right', Modern Law Review, 58, 37-53.

Van Bueren, G. (1998) The International Law on the Rights of the Child, Dordrecht: M. Nijhoff. 
Cerda, J. S. (1990) 'The draft Convention on the Rights of the Child: New rights', Human Rights Quarterly, 12, 115-19.

Choudhry, S. and Fenwick, H. (2005) 'Taking the rights of parents and children seriously: Confronting the welfare principle under the Human Rights Act', 25 Oxford Journal of Legal Studies, 3, 453-92.

Cottier, T. and Hertig, M. (2000) 'Das Völkerrecht in der neuen Bundesverfassung: Stellung und Auswirkungen' in U. Zimmerli (ed), Die neue Bundesverfassung: Konsequenzen für Praxis und Wissenschaft, Bern: Stämpfli, 1-22.

Daniels, K. (1995) 'Information sharing in donor insemination: A conflict of rights and ends', Cambridge Quarterly of Healthcare Ethics, 2, 217-24.

Detrick, S. (1999) A Commentary on the United Nations Convention on the Rights of the Child, The Hague: M. Nijhoff.

Eekelaar, J. (1994) 'The interests of the child and the child's wishes: The role of dynamic selfdeterminism' in P. Alston (ed), The Best Interests of the Child: Reconciling Culture and Human Rights. Oxford: Oxford University Press, 54.

Eekelaar, J. (2002) 'Beyond the welfare principle', Child and Family Law Quarterly, 14, 237-49.

Eekelaar, J. (2006) Family Law and Personal Life, Oxford: Oxford University Press.

Fortin, J. (2003) Children's Rights and the Developing Law, 2nd edn, London: Butterworths.

Fortin, J. (2006) 'Accommodating children's rights in a post Human Rights Act era', Modern Law Review, 69, 299-326.

Freeman, M. (1996) 'The new birth right?: Identity and the child of the reproductive revolution', 4 International Journal of Children's Rights, 3, 273-97.

Frith, L. (2001) 'Gamete donation and anonymity: The ethical and legal debate', 16 Human Reproduction, 5, 818-24.

Herring, J. (1999) 'The Human Rights Act and the welfare principle in family law: Conflicting or complementary?', Child and Family Law Quarterly, 11, 223-35.

Hodgkin, R. and Newell, P. (2002) The Implementation Handbook for the Convention on the Rights of the Child, New York: UNICEF.

Hodgson, D. (1993) 'The international legal protection of the child's right to a legal identity and the problem of statelessness', International Journal of Law, Policy and the Family, 7, 255-70.

LeBlanc, L. J. (1995) The Convention on the Rights of the Child: United Nations Lawmaking on Human Rights, Lincoln: University of Nebraska Press.

Masson, J. and Harrison, C. (1996) 'Identity: Mapping the frontiers' in N. Lowe and G. Douglas (ed), Families Across Frontiers, The Hague: M. Nijhoff, 277-94.

Nowak, M. (2005) UN Covenant on Civil and Political Rights: CCPR Commentary, 2nd edn, Kehl/ Strasbourg/Arlington: N.P. Engel.

O’Donovan, K. (1988) 'A right to know one's genetic parentage?', International Journal of Law Policy and the Family, 2, 27-45.

O'Donovan, K. (2000) 'Interpretations of children's identity rights' in D. Fottrell (ed), Revisiting Children's Rights, The Hague: Kluwer Law International, 73-85.

O'Donovan, K. (2002) "'Real” mothers for abandoned children', Law and Society Review, 36, 347-78.

Reusser, R. and Schweizer, R. (2000) 'Das Recht auf Kenntnis der Abstammung aus völker- und landesrechtlicher Sicht', Zeitschrift des Bernischen Juristenvereins, 605-36.

Ronen, Y. (2004) 'Redefining the child's right to identity', International Journal of Law, Policy and the Family, 18, 147-77.

Stewart, G. A. (1992) 'Interpreting the child's right to identity in the UN Convention on the Rights of the Child', Family Law Quarterly, 26, 221-33.

Swientek, C. (2001) Die Wiederentdeckung der Schande Babyklappen und anonym Geburt, Freiburg: Lambertus.

Triselotis, J. (1973) In Search of Origins: The Experiences of Adopted People, London: Routledge.

Wallbank, J. (2004) 'The role of rights and utility in instituting a child's right to know her genetic history', Social and Legal Studies, 13, 245-64.

Wilson, S. (1997) 'Identity, genealogy and the social family: The case of donor insemination', International Journal of Law, Policy and the Family, 11, 270-97. 